\title{
The gap between perceptions and expectations for measuring the quality of services provided by the Higher Technological Institute in Matrouh
}

\author{
Dr. / Abd Al Rahman Osman Abd Al Rahman Osman \\ Higher Technological Institute Tenth of Ramadan City Branch \\ Matrouh
}

\begin{abstract}
The main aim of the current study is to detect the gap between the perceptions of the Higher Technological Institute (Matrouh branch) students and their expectations for the level of service offered by the institute in different fields, then a stratified random sample of students (82 students 36 females and 46 males) were chosen. SERVQUAL gap scale which was prepared by Parasuraman and his colleagues (Parasuraman et al., 1985), was used to measure the quality of service at the Institute. The results showed that there is a negative gap statistically significant between the perceptions of students and their expectations for the total score for the level of service provided by the Institute, a decrease in the service provided by the Institute for learners level indicator, and the results showed the existence of a positive difference and is statistically significant in two dimensions: Reliability and Empathy, respectively while scholars showed a negative and statistically significant difference in the dimensions: Tangibles, Responsiveness and Assurance. The results showed the existence of significant differences between students perceived gap in the estimates and the expected level of service offered by the university back to the variables of sex and school year.
\end{abstract}




\section{The gap between perceptions and expectations Dr. / Abd Al Rahman Osman}

\section{Introduction}

In addition, the ability of any society to manage its vital development institutions and programs is not limited to focusing on the effectiveness and efficiency of these institutions, but also by focusing on its fairness and innovation as well as the extent to which its programs and services are suited to the expectations of the beneficiaries and their real ambitions for these services. The rapid change in economic, social and demographic principles has brought about urgent demands for quality of service provided by different institutions (Abu Hasan et al., 2008)

Higher education, like any other systematic system, is only a reflection of the general social and economic context in societies. It is not surprising that Arab higher education suffers from great problems. Its institutions face very serious challenges and threats, Science and technological development is based on high technology, progress, excellence and creativity, which leaves no room for hesitation in initiating comprehensive programs for development and modernization that ensure that Arab educational institutions have the ability to overcome on their problems and weaknesses (Douglas et al., 1993)

\section{Importance of the Study}

1-This research is considered an addition and completion to other related researches concerned with quality because of its significant results for the people who are interested in quality management.

2- This research deals with the higher education sector, which occupies great importance from the country, because it provides qualified scientific cadres ready for work.

\section{Objective of the Study}

The current study seeks to achieve the following objectives:

1-Identify the fundamental differences between student's perceptions and their expectations of the level of service elements provided at the Higher Technological Institute in Matrouh. 


\section{The gap between perceptions and expectations}

Dr. / Abd Al Rahman Osman

2-Identify the fundamental differences between learner's perceptions and expectations of the level of service components provided at the Higher Technological Institute in terms of gender.

3-Identify the fundamental differences between the learner's perceptions of the level of the elements of services provided at the Higher Institute of Technology in Matrouh. Depending on the years of study.

4-Identification of the fundamental differences between the expectations of students to the level of elements of services provided at the Institute of Higher Technology Matrouh depending on the variable years of study.

\section{The Research Problem}

Higher Technological Institute in Matrouh established Business Management Division and Information Technology (IT) to provide educational services in the field of technology business areas and to satisfy individual and society needs. It was noted that there was a continuous increase in the number of students. Thus, a pressing necessity for increasing qualitative need to meet the quantitative target is increasing number of students. It is the quality of the various services provided by the Institute, and to verify the nature and quality of these services have emerged the idea of this study, which focused its problem in their quest to identify the perceptions of students and their expectations for measuring the quality of services provided by the Higher Technological Institute in Matrouh level and its relation to variable school year and variable sex.

The problem of this study is to find answer for the following questions:

1-Are there differences between the learner's perceptions and expectations of the level of services provided at the Higher Institute of Technology in Matruh?

2-Are there differences between the learner's perceptions and their expectations of the level of services provided at the Higher Institute of Technology in Matrouh due to the gender variable?

مجلة الدراسات المالية والتجارية




\section{The gap between perceptions and expectations}

Dr. / Abd Al Rahman Osman

3-Are there differences between the student's perceptions of the level of services provided at the Higher Institute of Technology in Matrouh due to the variable years of study?

4-Are there differences between the expectations of the students for the level of services provided at the Higher Institute of Technology in Matrouh due to the variable years of study?

\section{Hypotheses of the Study}

Research hypotheses

1-There are substantial differences between the student's perceptions and their expectations of the level of services provided by the Higher Technological Institute in Matruh.

2. There are substantial differences between the student's perceptions and their expectations of the level of services provided at the Higher Technological Institute in Matrouh due to the gender variable.

3-There are significant differences between the perceptions of the students for the level of services provided by the Higher Technological Institute in Matrouh due to the variable years of study.

4-There are significant differences between the expectations of the students for the level of services provided by the Higher Technological Institute in Matrouh due to the variable years of study.

\section{Background Study}

It is true that quality is the option that is difficult to get the thesis of flexibility when talking about the quality of university education, so there is another way to improve the performance of universities is Quality; the end is purely to meet the benefits of degradation and stunting. The progress of our societies is determined by the recognition that the future of our societies is determined in the corridors of our universities, terraces, laboratories and laboratories. This gives us the size and the kind of effort required in order for our

229

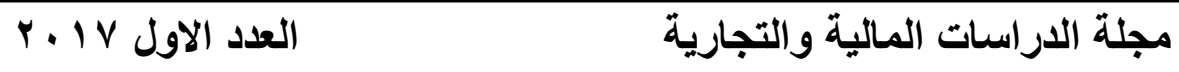




\section{The gap between perceptions and expectations Dr. / Abd Al Rahman Osman}

steps to be in the right direction. Its standards, references and objectives Gianesi and Correa (2004).

The adherence to the national peculiarities of our universities does not intersect with the need to attract international standards of quality under the umbrella of academic accreditation. Thus, the university education systems in many Arab countries have shown a tendency and consistency with international standards and systems with a bias towards those of leadership, in the social and economic development of the community(Al-Alak \& Alnaser, 2012).

Since TQM is one of the modern management concepts that emerged as a result of the fierce global competition between the Japanese and American production institutions, on the one hand, and the American and the European, on the other, in order to obtain consumer satisfaction, it was by the world Deming. Which was described as the father of total quality and given the success achieved by this concept in the economic, industrial, commercial and technological organizations in developed countries and the emergence of competition between these industrial organizations to obtain the best product and customer satisfaction, the interest of educational institutions in the application of TQM in the field of public education and university education In particular to get better quality of learning Coelho (2004).

The number of TQM institutions is increasing in both the US, European countries, Japan, and many developing countries and some Arab countries such as Saudi Arabia and Kuwait, which have started to practice this approach in some of their educational institutions (Jongbloed et al. 2008).

Total Quality Management (TQM) is a management philosophy based on the concept of systems that looks at the organization in a comprehensive manner to make desired positive changes by addressing every part of the organization and developing it in the desired manner to achieve better (Pereira, 2004).

Quality is essentially an economic term that has emerged based on the industrial and technological competition between the advanced industrial countries in order to control the quality of production and gain the confidence of the market and the buyer. Therefore, the quality 


\section{The gap between perceptions and expectations Dr. / Abd Al Rahman Osman}

is focused on the excellence and excellence of the quality of the product in any field. And overcome them to the best of them, "and therefore the beneficiary to determine the quality of the required and that meet his wishes and satisfaction, and here is the challenge and difficulty to satisfy all the beneficiaries and who vary their whims and desires and have different personalities and belong to different social classes (Khodayari \& Khodayari, 2011).

The concept of quality in education is about all the characteristics related to the field of education, which shows the quality of the results to be achieved. It is to translate the needs of the students' expectations into specific characteristics that are mainly in their education and training for the generalization of the educational service and its formulation according to objectives in line with the expected aspirations of the students Meirelles (2006).

Thus, the overall quality seeks to prepare the students with certain characteristics that enable them to experience the richness of information, the continuous processes of change and the tremendous technological progress, so that their role is not only in the transfer of knowledge and listening; but in the process of dealing with this information and benefiting from it sufficiently to serve the learning process, In the role of educational institution, teacher and academic supervisor, so as to provide an educational environment that allows freedom of expression and discussion and help students to selflearning and cooperative, and this approach commensurate with the method and philosophy of distance learning pursued by universities Which depends on the learner in the learning process while providing all the necessary opportunities for learning with the help of the academic supervisor(Amelia, Hidayanto, \& Hapsari, 2011).

The measurement process is one of the main axes of product and service quality development. It is stated that what can't be measured can't be developed. It is not possible to determine the extent of development or decline of production efficiency and the level of service provided without using one or more measuring instruments (Akter, Upal \& Hani, 2008).

The existence of a tightly controlled system is the first step of integration and innovation in the development of the quality of

231

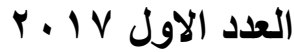
مجلة الدراسات المالية والتجارية 


\section{The gap between perceptions and expectations Dr. / Abd Al Rahman Osman}

services and products. The use of modern technology and statistical methods supports the efficiency of production and service processes. The quality of the educational services provided by the university can be measured by measuring several aspects, the most important of which are: the extent of student achievement, the degree of satisfaction of students and their parents, the level of university graduates, the level of teachers and administrators, administrative efficiency, optimal use of financial and human resources, Offered by the University Maric (2013).

Salis(1993) believes that the quality of comprehensive educational services has two main perspectives: first, the degree to which the director matches the specifications set for them, and this is the perspective of the producer who is keen to match the produced product with its design. The second perspective shows the extent to which the need of the client or the beneficiary of the service is met. This is the perspective of perception, impression, expectation or ambition.

Although these two perspectives have been developed for use in industry and productive management, many educators and researchers believe that they can be applied to the educational process. The first perspective can be verified largely by matching the product to the specifications already planned, May include external dimensions that include providing the student with many functional skills. For the second perspective, Harris and Breedy (1997), in their study on the effectiveness of management in education, believe that the client can be seen in this perspective to include students, parents, education financiers, and employers.

There are several basic models for measuring the quality of services provided by the educational institution within these institutions, the most important of which are (Davis, 2002):

1-Quality Control Service: This control comes after the production process to detect and remove any defective elements of this production, and in the educational process means quality control process to identify any manifestations of vulnerability are explored after the completion of the educational process, and exercise this

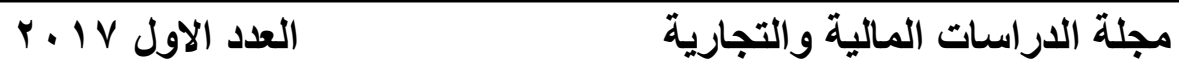




\section{The gap between perceptions and expectations Dr. / Abd Al Rahman Osman}

control using tests and tests External and internal, and by writing reports and preparing studies, and taking the opinion of parents.

2-Quality assurance: This process is done before and during the educational process and not after it as in quality control, and the quality is an integral part of the products or outputs themselves, and here can be applied specifications, and seek to prevent any defect or defect, The model or the starting point for the educational process, since the achievement of some educational goals does not depend on the educational institution alone, but there are many variables and conditions can interfere with the effects in the educational process.

3-Quality Management System: This system is based on the management and control of employees in the institution, and aims to integrate the work with the necessary mechanisms to ensure the quality at each stage of the educational process, that is to do the following operations: planning the production process and control, Agree on appropriate strategies to achieve those results, and constantly review and monitor the educational system.

4-Total Quality Management: This model is an extension and development of the quality assurance system, and seeks to make every member of the institution willing to satisfy the customer, and to make the system of the institution able to allow them, and is basically concerned with organizational improvement that focuses on the customer and depends on Imagine his perception and expectation of the quality of service provided to him.

In order to measure the quality of services according to the latest TQM-based model, different tools have been developed and adopted. However, the most recent use of this approach is the gap between the perception and expectations of individuals to measure quality of service. Paracharaman and his colleagues developed a tool based on the idea of defining the gap Between the reality of the level of service and the customer's expectation of the level of service that must be provided to him. This has been adopted to achieve the objectives of this study after the development of the Paracharman scale to suit the quality of educational services in order to identify the difference between the perceptions of students at the Higher Technological

233

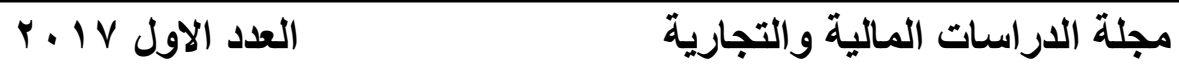




\section{The gap between perceptions and expectations Dr. / Abd Al Rahman Osman}

Institute and their expectations of the level of service provided by the university (Parasuraman et al., 1988).

Quality in a service organization is a measure of the range to which the service delivered meets the customer's expectations. The characteristics of service consist of intangibility, heterogeneity and inseparability. Quality as defined for higher education has been identified by Harvey and Knight (1996). They suggested that quality reflects exceptional, consistency, fitness for purpose, value for money, and transformative.

Research on service quality gained a major push forward in the early 1980s. A number of researchers posit that service quality involves a comparison of expectations with performance. Lewis and argued that service quality is a measure of how well the service level delivered matches customer expectations. Gronroos (1984) identified two dimensions of service quality namely functional quality — which involves the performance in which the service delivered and technical quality -- the actual outcome of the service. Finally, Parasuraman, Zeithaml and Berry (1985) conceptualized service quality using a disconfirmation model that assesses customer's expectations and perceptions, with development and subsequent refinement in 1988 and 1991 of the SERVQUAL instrumentation (Parasuraman, Zeithaml, \& Berry, 1991).

\section{Study Community \& Sample}

The study population consists of all students enrolled for all academic years in the second semester of the academic year 2016/2017 at the Higher Institute of Technology in Matrouh. According to official data, the total number of students enrolled in the study is 725 students, 406 students, 56\%, 319 students and $44 \%$. The sample of the study consisted of 82 students studying at a rate of $11 \%$ of the original society. The sample of the study sample was randomly selected according to gender variable. A number of male and female students were selected from the sample specified in this study. The sample of the study was distributed as shown in the following table: 


\section{The gap between perceptions and expectations}

\section{Dr. / Abd Al Rahman Osman}

Table 1. Population and sample structure according to the year of study and gender

\begin{tabular}{|l|l|l|}
\hline Description & \multicolumn{1}{|c|}{$\begin{array}{c}\text { Number of } \\
\text { students in the } \\
\text { population }\end{array}$} & $\begin{array}{c}\text { Number of } \\
\text { students in the } \\
\text { sample (stratified) }\end{array}$ \\
\hline Year of study & & \\
\hline 1 & 178 & 20 \\
\hline 2 & 138 & 16 \\
\hline 3 & 178 & 20 \\
\hline 4 & 235 & 26 \\
\hline Gender & & \\
\hline Female & 319 & 36 \\
\hline Male & 406 & 46 \\
\hline Total & 725 & 82 \\
\hline
\end{tabular}

\section{Study tool}

The tool of the present study is the gap measurement of the quality of service, which was originally prepared (Parasuraman \& Others, 1988), known as SERVQUAL, an abbreviation of Service and Quality or Quality. Consumer services in some aspects of commercial and productivity, and then its uses and applications were subsequently used in various educational fields, health services, information and technology centers, banking, air, land and sea transport, education, engineering service, fast food, cleaning service, technical and industrial information service The Axis Key to measuring the quality of service of this scale is the gap between the beneficiary's perception of the actual performance of the service and its expectations about the quality of the service (Oakland, 1995). This gap is in five consecutive gaps in the five areas covered by the scale, (Parasuraman et al., 1988) The five areas are described below and a description of the variables they include:

1-(Tangible): The field of material physical aspects and includes variables related to equipment, materials, buildings and facilities and attractiveness, which measure the availability of modernity of form and physical appearance of the service provided by the institution. 


\section{The gap between perceptions and expectations}

Dr. / Abd Al Rahman Osman

2-Reliability: The area of reliability and contains the variables related to the fulfillment of the institution's various commitments and promises promised by the beneficiaries, and its interest in solving outstanding problems, and measure accuracy and objectivity and health in the provision of services.

3-Responsiveness: The area of response This field includes those variables that measure the speed of the response of the organization to provide timely service, and the extent of its employees 'keenness to provide immediate services to the beneficiaries, and the extent of the employees' cooperation with the beneficiaries.

4-Assurance: It contains variables related to ensuring the instilling of mutual trust between employees and beneficiaries, generating a sense of acceptance, providing safety and security means to the beneficiaries, informing employees about the information they deal with, and ensuring proper training to provide the service without problems or mistakes.

5-Empathy: The field of social empathy This field includes variables that concern the interest of the employees of the beneficiaries of personal service, and understand their personal, social and emotional needs, and measures the extent to which employees show relations with the beneficiaries based on respect, friendliness, friendship and satisfaction.

\section{Field Study Results}

\section{a. Study results for the First Hypothesis}

1-There are substantial differences between the student's perceptions and their expectations of the level of services provided by the Higher Technological Institute in Matruh. 


\title{
The gap between perceptions and expectations
}

\author{
Dr. / Abd Al Rahman Osman
}

Table 3: The difference between the statistical means of the perceptions of students and their expectations for the level of service provided by the Institute in regard of the elements and the value of $(\mathrm{t})$ calculated.

\begin{tabular}{|c|c|c|c|c|c|c|}
\hline No. & Dimensions and Items & 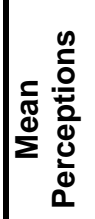 & 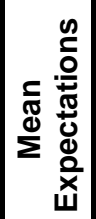 & 음 & $\mathbf{T}$ & Sig. \\
\hline & Tangibles & & & & & \\
\hline 1 & $\begin{array}{l}\text { The availability of modern equipment and } \\
\text { appropriate techniques. }\end{array}$ & 3.23 & 3.65 & -0.42 & $-5.220^{\star}$ & .000 \\
\hline 2 & attractive Equipment And buildings. & 3.63 & 3.80 & -0.17 & $-4.084^{\star}$ & .000 \\
\hline 3 & $\begin{array}{l}3 \text { - The overall appearance of staff and } \\
\text { staff is elegant. }\end{array}$ & 3.76 & 3.70 & 0.06 & $2.293^{\star}$ & .024 \\
\hline 4 & $\begin{array}{l}\text { Attractiveness materials and disciplines } \\
\text { and decisions. }\end{array}$ & 3.73 & 3.68 & 0.05 & $2.038^{\star}$ & .045 \\
\hline & \begin{tabular}{|c|} 
Total Tangibles \\
\end{tabular} & 3.58 & 3.70 & -0.12 & $-4.618^{\star}$ & .000 \\
\hline & \begin{tabular}{|c|} 
Reliability \\
\end{tabular} & & & & & \\
\hline 5 & Meet educational service delivery on time. & 3.67 & 3.63 & 0.04 & 1.754 & .083 \\
\hline 6 & $\begin{array}{l}\text { Availability of the number Adequate From } \\
\text { employees And teachers. }\end{array}$ & 3.63 & 3.77 & -0.14 & $-2.254^{*}$ & .027 \\
\hline 7 & $\begin{array}{l}\text { Take care of solve different problems for } \\
\text { learners. }\end{array}$ & 3.71 & 3.68 & 0.03 & .532 & .596 \\
\hline 8 & $\begin{array}{l}\text { Maintaining With records And files } \\
\text { Accurate. }\end{array}$ & 3.85 & 3.84 & 0.01 & .445 & .657 \\
\hline 9 & $\begin{array}{l}\text { Accuracy And not Errors at Submit } \\
\text { different Services. }\end{array}$ & 3.85 & 3.82 & 0.03 & .686 & .495 \\
\hline 10 & $\begin{array}{l}\text { Inform students of exams, seminars, etc. } \\
\text { in a timely manner. }\end{array}$ & 3.84 & 3.78 & 0.06 & 1.149 & .254 \\
\hline & \begin{tabular}{|c|} 
Total Reliability \\
\end{tabular} & 3.76 & 3.75 & 0.01 & .291 & .772 \\
\hline & \begin{tabular}{|c|} 
Responsiveness \\
\end{tabular} & & & & & \\
\hline 11 & $\begin{array}{l}\text { Response Instant Messaging For student's } \\
\text { problems. }\end{array}$ & 3.59 & 3.65 & -0.06 & $-2.293^{*}$ & .024 \\
\hline 12 & Ready and willing staff to assist students. & 3.56 & 3.65 & -0.09 & $-2.157^{\star}$ & .034 \\
\hline 13 & $\begin{array}{l}\text { Constant readiness to cooperate with } \\
\text { learners to solve outstanding issues. }\end{array}$ & 3.63 & 3.60 & 0.03 & 1.754 & .083 \\
\hline & \begin{tabular}{|c|} 
Total Responsiveness \\
\end{tabular} & 3.59 & 3.63 & -0.04 & $-2.235^{\star}$ & .028 \\
\hline & Assurance & & & & & \\
\hline 14 & $\begin{array}{l}\text { Behavior of employees Boosts Feeling } \\
\text { Safe and trust in student. }\end{array}$ & 3.87 & 3.78 & 0.09 & $2.750 *$ & .007 \\
\hline 15 & $\begin{array}{l}\text { The Institute implements programs of } \\
\text { study according to the specialization of } \\
\text { students. }\end{array}$ & 3.78 & 3.73 & 0.05 & $2.038^{\star}$ & .045 \\
\hline
\end{tabular}

237

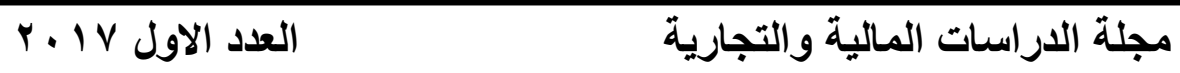




\title{
The gap between perceptions and expectations
}

\author{
Dr. / Abd Al Rahman Osman
}

\begin{tabular}{|c|l|c|c|c|c|c|}
\hline 16 & $\begin{array}{l}\text { The educational process is provided with } \\
\text { high quality. }\end{array}$ & 3.67 & 3.90 & -0.23 & $-3.531^{\star}$ & .001 \\
\hline 17 & $\begin{array}{l}\text { Knowledge of staff with adequate } \\
\text { information and well delivered. }\end{array}$ & 3.65 & 3.76 & -0.11 & $-3.160^{\star}$ & .002 \\
\hline 18 & $\begin{array}{l}\text { The Institute shall treat the student's } \\
\text { information in confidence. }\end{array}$ & 3.63 & 3.76 & -0.13 & $-3.027^{\star}$ & .003 \\
\hline 19 & $\begin{array}{l}\text { Faculty members answer questions from } \\
\text { students professionally. }\end{array}$ & 3.67 & 3.60 & 0.07 & $2.529^{\star}$ & .013 \\
\hline & \multicolumn{1}{|c|}{ Total Assurance } & 3.71 & 3.75 & -0.04 & $-2.905^{\star}$ & .005 \\
\hline 20 & $\begin{array}{l}\text { Staff appears friendly at their relationship } \\
\text { with student. }\end{array}$ & 3.83 & 3.76 & 0.07 & $2.529^{\star}$ & .013 \\
\hline 21 & $\begin{array}{l}\text { Interest of the student placed in the } \\
\text { forefront of the Administration. }\end{array}$ & 3.76 & 3.67 & 0.09 & $2.750^{\star}$ & .007 \\
\hline 22 & $\begin{array}{l}\text { Cheerful Spirit and Friendship Clear at } \\
\text { Dealing inside Institute. }\end{array}$ & 3.74 & 3.70 & 0.04 & $2.038^{\star}$ & .045 \\
\hline 23 & $\begin{array}{l}\text { The Institute provides an opportunity for } \\
\text { festivities and excursions, acquaintance. }\end{array}$ & 3.73 & 3.68 & 0.05 & 1.650 & .103 \\
\hline 24 & $\begin{array}{l}\text { Respect for the guests of the Institute and } \\
\text { his visitors and greet them warmly. }\end{array}$ & 3.66 & 3.74 & -0.08 & $-2.157^{\star}$ & .034 \\
\hline 25 & $\begin{array}{l}\text { The Institute carefully examines the } \\
\text { feedback to develop operations. }\end{array}$ & 3.63 & 3.71 & -0.08 & $-2.169^{\star}$ & .033 \\
\hline & Total Empathy & 3.73 & 3.71 & 0.02 & 1.238 & .219 \\
\hline & 3.69 & 3.72 & -0.03 & $-3.427^{\star}$ & .001 \\
\hline
\end{tabular}

The findings in the previous timetable showed that the students' assessment to the level of quality of service provided by the Higher Technological Institute in Matrouh as measured by the differences between the average perception and expectations of each of the questions, which include the five dimensions. The results analysis showed the following points:

1 - The assessment of students to the level of service provided by the Higher Technological Institute according to the gap between perceptions and expectations were positive and statistically significant in the questions (elements, variables).

(3) " The overall appearance of staff and staff is elegant." (0.06), and (4) "Attractiveness materials and disciplines and decisions." (0.05), and (14) "Behavior of employees Boosts Feeling Safe and trust in student." (0.09), and (15) "The Institute implements programs of study according to the specialization of students." (0.05), and (19) "Faculty members answer questions from students professionally." (0.07), and (20) "Staff appears friendly at their relationship with 


\section{The gap between perceptions and expectations Dr. / Abd Al Rahman Osman}

student." (0.07), and (21) "Interest of the student placed in the forefront of the Administration." (0.09), and (22) "Cheerful Spirit and Friendship Clear at Dealing inside Institute." (0.04).

2 - The assessment of students to the level of service provided by the Higher Technological Institute according to the gap between perceptions and expectations were positive and statistically significant in the questions (elements, variables).

(5) " Meet educational service delivery on time." (0.04), and (7) "Take care of solve different problems for learners." (0.03), and (8) "Maintaining With records And files Accurate." (0.01), and (9) "Accuracy And not Errors at Submit different Services." (0.03), and (10) "Inform students of exams, seminars, etc. in a timely manner." (0.06), and (13) "Constant readiness to cooperate with learners to solve outstanding issues." (0.03), and (23) "The Institute provides an opportunity for festivities and excursions, acquaintance." (0.05).

3- The assessment of students to the level of service provided by the Higher Technological Institute according to the gap between perceptions and expectations were negative and statistically significant in the questions (elements, variables).

(1)" The availability of modern equipment and appropriate techniques." (-0.42), and (2) " attractive Equipment And buildings." (0.17), and (6) " Availability of the number Adequate From employees And teachers." (-0.14), and (11) " Response Instant Messaging For student's problems." (-0.06), and (12) " Ready and willing staff to assist students." (-0.09), and (16) " The educational process is provided with high quality." (-0.23), and (17) " Knowledge of staff with adequate information and well delivered." (-0.11), and (18) " The Institute shall treat the student's information in confidence." (-0.13), and (24) " Respect for the guests of the Institute and his visitors and greet them warmly." (-0.08), and (25) " The Institute carefully examines the feedback to develop operations." (-0.08) .

4-According to the level of the five dimensions of service provided by the Institute, learners have given a positive assessment of and non-statistically significant in the following two dimensions: the second dimension Reliability (0.01), and the fifth dimension Empathy (0.02). on the other hand they have shown a negative 


\section{The gap between perceptions and expectations Dr. / Abd Al Rahman Osman}

assessment and non-statistically significant in the other dimensions:

The first dimension Tangibles (-0.12), and the third dimension Responsiveness (-0.04), and the fourth dimension Assurance (-0.04). The total score of the provided deduced from these results stated that the general difference between perception average and learners expectations ranged to -0.03 which considered negative and statistically significant. It is an indicator of the poor level of services provided by the Institute from the perspective of students' point of view.

Of the total of these results it can be concluded that the dimensions Reliability and Empathy was of a positive assessment, but is not statistically significant. While the dimensions Tangibles, Responsiveness and Assurance had a negative impact and statistically significant, and confirms the urgent need to re-examine all the elements (questions) five dimensions, especially dimensional Tangibles, Responsiveness and Assurance and containing them from the elements (questions) in order to be adjusted in a desirable direction , in order to raise the standard of quality of service offered by the institute so that less or fade differences between what learners actually realize what they expect of them.

Based on the above we can accept the validity of the first hypothesis 'There are significant differences between the perceptions of students and their expectations for the level of service elements provided in Higher Technological Institute in Matrouh.

\section{b. Study Results Related to Second Hypothesis}

2. There are substantial differences between the student's perceptions and their expectations of the level of services provided at the Higher Technological Institute in Matrouh due to the gender variable. 


\section{The gap between perceptions and expectations}

\section{Dr. / Abd Al Rahman Osman}

Table 4: The statistical means, medians, standard deviations, and the results of the test " $\mathrm{T}$ " of the significance of differences between learners / students estimates perceived and projected to the level of service areas provided by the institute according to gender

\begin{tabular}{|c|c|c|c|c|c|c|c|}
\hline \multirow{2}{*}{ Dimensions } & \multirow{2}{*}{ Gap } & \multicolumn{2}{|c|}{ Male } & \multicolumn{2}{|c|}{ Female } & \multirow[b]{2}{*}{$\mathbf{t}$} & \multirow[b]{2}{*}{ Sig. } \\
\hline & & Mean & $\begin{array}{l}\text { Std. } \\
\text { dev. }\end{array}$ & Mean & $\begin{array}{l}\text { Std. } \\
\text { dev. }\end{array}$ & & \\
\hline \multirow{2}{*}{ Tangibles } & Perceptions & 3.673 & .237 & 3.521 & .257 & 2.742 & .008 \\
\hline & Expectations & 3.701 & .259 & 3.712 & .252 & -.186 & .853 \\
\hline \multirow{2}{*}{ Reliability } & Perceptions & 3.773 & .211 & 3.750 & .171 & .548 & .585 \\
\hline & Expectations & 3.763 & .188 & 3.746 & .212 & .388 & .699 \\
\hline \multirow{2}{*}{ Responsiveness } & Perceptions & 3.601 & .354 & 3.587 & .255 & .221 & .826 \\
\hline & Expectations & 3.620 & .266 & 3.637 & .270 & -.290 & .773 \\
\hline \multirow{2}{*}{ Assurance } & Perceptions & 3.763 & .170 & 3.670 & .200 & 2.238 & .028 \\
\hline & Expectations & 3.796 & .178 & 3.721 & .179 & 1.889 & .062 \\
\hline \multirow{2}{*}{ Empathy } & Perceptions & 3.750 & .166 & 3.706 & .211 & 1.012 & .315 \\
\hline & Expectations & 3.773 & .183 & 3.659 & .213 & 2.544 & .013 \\
\hline \multirow{2}{*}{ Total } & Perceptions & 3.728 & .117 & 3.664 & .108 & 2.573 & .012 \\
\hline & Expectations & 3.746 & 107 & 3.700 & .111 & 1.876 & .064 \\
\hline
\end{tabular}

1- For the physical aspects and concrete Tangibles There is a difference between the perceptions of students, male and female, and this was in favor of males, and there is no significant difference between the students, male and female expectations. 


\section{The gap between perceptions and expectations} Dr. / Abd Al Rahman Osman

2-For Reliability results indicate that in the previous table that there is no statistically significant differences between the students perceived and the expected level of service provided by the Technological Institute estimates dating back to the variable of sex, in the sense that there is no fundamental difference between the perceptions of male and female expectations for the level of service provided by the Institute.

3-For Responsiveness results indicate that in the previous table that there is no statistically significant differences between the students perceived and the expected level of service provided by the Technological Institute estimates dating back to the variable of sex, in the sense that there is no fundamental difference between the perceptions of male and female and their expectations for the level of service provided by the Institute.

4-For Assurance there is a difference between the perceptions of students, male and female, and this was in favor of males, and there is no significant difference between the students, male and female expectations.

5-For the aspects of empathy there is no difference between the perceptions of students, male and female, and this was in favor of males, and no significant difference between the students, male and female expectations and this was in favor of males.

6- In total there is a difference between students' perceptions (male and female) and this was in favor of males, and there was no difference between the expectations of students (male and female).

Based on the above we can accept the validity of the second hypothesis, there are substantial differences between the perceptions of students and their expectations for the level of service provided in the areas of Higher Technological Institute in Matrouh based on the gender variable.

\section{c. Study Results Related to Third Hypothesis}

3-There are significant differences between the perceptions of the students for the level of services provided by the Higher Technological Institute in Matrouh due to the variable years of study.

242

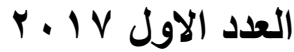
مجلة الدراسات المالية والتجارية 


\section{The gap between perceptions and expectations \\ Dr. / Abd Al Rahman Osman}

Table 5: Results of the variance of the significance of differences between the mean estimates of learner's different areas analysis of their perception of the level of service in depending on the variable-years of study

\begin{tabular}{|c|c|c|c|c|c|c|}
\hline Dimensions & Source & $\begin{array}{l}\text { Sum of } \\
\text { Squares }\end{array}$ & df & $\begin{array}{c}\text { Mean } \\
\text { Square }\end{array}$ & $\mathbf{F}$ & Sig. \\
\hline \multirow{3}{*}{ Tangibles } & Between Groups & .949 & 3 & .316 & \multirow{3}{*}{5.514} & \multirow{3}{*}{.002} \\
\hline & Within Groups & 4.473 & 78 & .057 & & \\
\hline & Total & 5.421 & 81 & & & \\
\hline \multirow{3}{*}{ Reliability } & Between Groups & .239 & 3 & .080 & \multirow{3}{*}{2.345} & \multirow{3}{*}{.079} \\
\hline & Within Groups & 2.655 & 78 & .034 & & \\
\hline & Total & 2.894 & 81 & & & \\
\hline \multirow{3}{*}{ Responsiveness } & Between Groups & .126 & 3 & .042 & \multirow{3}{*}{.454} & \multirow{3}{*}{.715} \\
\hline & Within Groups & 7.213 & 78 & .092 & & \\
\hline & Total & 7.339 & 81 & & & \\
\hline \multirow{3}{*}{ Assurance } & Between Groups & .237 & 3 & .079 & \multirow{3}{*}{2.226} & \multirow{3}{*}{.092} \\
\hline & Within Groups & 2.766 & 78 & .035 & & \\
\hline & Total & 3.003 & 81 & & & \\
\hline \multirow{3}{*}{ Empathy } & Between Groups & .074 & 3 & .025 & \multirow{3}{*}{.654} & \multirow{3}{*}{.583} \\
\hline & Within Groups & 2.947 & 78 & .038 & & \\
\hline & Total & 3.021 & 81 & & & \\
\hline \multirow{3}{*}{ Total } & Between Groups & .163 & 3 & .054 & \multirow{3}{*}{4.532} & \multirow{3}{*}{.006} \\
\hline & Within Groups & .937 & 78 & .012 & & \\
\hline & Total & 1.100 & 81 & & & \\
\hline
\end{tabular}

Table 6: Special dimension Tangibles Touques test results

\begin{tabular}{|cc|c|c|c|c|}
\hline \multicolumn{2}{|c|}{ Year } & \multicolumn{4}{c|}{ Mean Difference (I-J) } \\
\cline { 3 - 6 } & 1 & 2 & 3 & 4 \\
\hline 1 & 3.6875 & - & .03125 & .05000 & $.25481^{*}$ \\
\hline 2 & 3.6563 & - & - & .01875 & $.22356^{*}$ \\
\hline 3 & 3.6375 & - & - & - & $.20481^{*}$ \\
\hline 4 & 3.4327 & - & - & - & - \\
\hline
\end{tabular}

- Concerning dimension of Tangibles there are some significant differences between students' perceptions to the level of service provided in the areas of the Institute, and by the test of Touques analysis to know the difference between the average years of study which shows the following: 


\section{The gap between perceptions and expectations}

Dr. / Abd Al Rahman Osman

1/1- The differences between the statistical means of the first and second year and the third is not statistically significant

$1 / 2$ - There is a difference between the statistical means of the fourth year and the previous three years.

r- For the dimensions of Reliability, Responsiveness, Empathy and Assurance there are no significant differences between students' perceptions to the level of service provided in the areas of Institute

3- In total there are significant differences between students' perceptions to the level of service provided in the areas of Institute

Based on the above we can accept the validity of the third hypothesis, there are significant differences between students' perceptions to the level of service provided in the areas of Higher Technological Institute in Matrouh due to the years of the study variable.

\section{d. Study Results Related to Fourth Hypothesis:}

4-There are significant differences between the expectations of the students for the level of services provided by the Higher Technological Institute in Matrouh due to the variable years of study. 


\section{The gap between perceptions and expectations}

\section{Dr. / Abd Al Rahman Osman}

Table 7: The analysis outcomes of the variance of the significance of differences between the mean estimates of studying learners' expectations for the level of service in different areas depending on the analysis of the years of study variable.

\begin{tabular}{|c|c|c|c|c|c|c|}
\hline Dimensions & Source & $\begin{array}{l}\text { Sum of } \\
\text { Squares }\end{array}$ & df & $\begin{array}{l}\text { Mean } \\
\text { Square }\end{array}$ & $\mathbf{F}$ & Sig. \\
\hline \multirow{3}{*}{ Tangibles } & $\begin{array}{l}\text { Between } \\
\text { Groups }\end{array}$ & .034 & 3 & .011 & \multirow{3}{*}{.170} & \multirow{3}{*}{.916} \\
\hline & Within Groups & 5.192 & 78 & .067 & & \\
\hline & Total & 5.226 & 81 & & & \\
\hline \multirow{3}{*}{ Reliability } & $\begin{array}{c}\text { Between } \\
\text { Groups }\end{array}$ & .164 & 3 & .055 & \multirow{3}{*}{1.366} & \multirow{3}{*}{.259} \\
\hline & Within Groups & 3.126 & 78 & .040 & & \\
\hline & Total & 3.290 & 81 & & & \\
\hline \multirow{3}{*}{ Responsiveness } & $\begin{array}{c}\text { Between } \\
\text { Groups }\end{array}$ & .098 & 3 & .033 & \multirow{3}{*}{.451} & \multirow{3}{*}{.718} \\
\hline & Within Groups & 5.681 & 78 & .073 & & \\
\hline & Total & 5.779 & 81 & & & \\
\hline \multirow{3}{*}{ Assurance } & $\begin{array}{c}\text { Between } \\
\text { Groups }\end{array}$ & .152 & 3 & .051 & \multirow{3}{*}{1.561} & \multirow{3}{*}{.206} \\
\hline & Within Groups & 2.527 & 78 & .032 & & \\
\hline & Total & 2.679 & 81 & & & \\
\hline \multirow{3}{*}{ Empathy } & $\begin{array}{l}\text { Between } \\
\text { Groups }\end{array}$ & .271 & 3 & .090 & \multirow{3}{*}{2.190} & \multirow{3}{*}{.096} \\
\hline & Within Groups & 3.218 & 78 & .041 & & \\
\hline & Total & 3.489 & 81 & & & \\
\hline \multirow{3}{*}{ Total } & $\begin{array}{l}\text { Between } \\
\text { Groups }\end{array}$ & .089 & 3 & .030 & \multirow{3}{*}{2.532} & \multirow{3}{*}{.063} \\
\hline & Within Groups & .916 & 78 & .012 & & \\
\hline & Total & 1.005 & 81 & & & \\
\hline
\end{tabular}

The above table refers to a lack of statistically significant differences between the average of expectations of the students to the level of service offered by the institute in various fields and in the total sum of these areas depending on the variable-years of study, which estimates the sense that all learners regardless of the school year, have estimated their expectations for the level of service provided by the Institute at the same level. 


\section{The gap between perceptions and expectations} Dr. / Abd Al Rahman Osman

\section{Conclusions}

Based on the above results, it can be said that the service provided by the Higher Technological Institute in Matrouh, subject of study, the level was positive and provides an abstract significance concerning some variables, compared to the gap between the average perceptions and expectations of students for this service, so the variables of sex and years of study of the impact; there is also negative rates for some variables that showed statistically significant differences for some of these averages, so that it can be attributed to gender or specialization, but the differences were huge and this led to the fact that students, whether they are male or female, and whether they are in different years of study have evaluated their estimates as measured by the gap between the perceptions and expectations of the level of assessment service negative overall. This may be due to a narrow geographical area of Matrouh Governorate, which reduces the gap between students in knowing institute's news and get to know what its services and expertise, in addition to the fact that the institute is the most common and attractive to students in the trade area in the province; which makes community members and students specifically post-secondary technical more interactive with the Institute through recognizing its projects, programmes, specializations and all other available activities.

\section{Recommendations}

\section{In light of the findings, the researcher suggests the following recommendations:}

1. The researcher advises the Institute Board to focus on the areas of service and all what it includes in the different elements that make a difference. Students showed negative significance in the level of service particularly in the materials and authorizations areas to review them thoroughly and improve the level of services provided to the students in these areas and all other elements.

2. Giving due care and attention to the areas of safety, security and social responsiveness, empathy and its various elements, which showed a positive assessment of the students and development to remain in a good and attractive level.

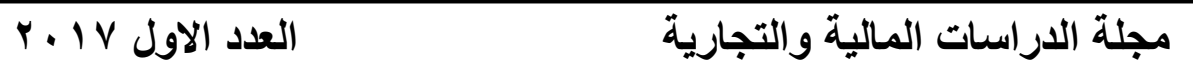




\section{The gap between perceptions and expectations}

Dr. / Abd Al Rahman Osman

3. The researcher advices other researchers to give due attention and focus on further studies and researches in this area in different regions and educational centers in order to ensure that quality service provided by the Institute.

4. Implementing further studies and researches in this area deals with other variables from the viewpoint of other categories of nonstudents such as supervisors, academics, administrators and others stakeholders who are concerned in process of service offered by the university to find out objective criteria to assess the service quality that is provided by the Higher Technological Institute in Matrouh.

5. In order to get objective facts in this field the researcher recommends conducting intensive cross-sectional and longitudinal studies in which the study individuals will be students in high school to identify the possible expectations regarding the service provided by the Higher Technological Institute, and then follow up the same students after their enrollment in the Higher Technological Institute to know the actual awareness and perceptions for the provided services. 


\section{The gap between perceptions and expectations Dr. / Abd Al Rahman Osman}

\section{References}

Abu Hasan, H. F., Ilias, A., Abd Rahman, R., \& Abd Razak, M. Z. (2008). Service quality and student satisfaction: A case study at private higher education institutions. International Business Research, 1(3), 163-175.

Akter, M. S., Upal, M., \& Hani, U. (2008). Service quality perception and satisfaction: A Study over sub-urban public hospitals in Bangladesh., Journal of Services Research, Special Issue, 125-146.

Al-Alak, B. A., \& Alnaser, A. S. M. (2012). Assessing the relationship between higher education service quality dimensions and student satisfaction. Australian Journal of Basic and Applied Sciences, 6(1), 156-164.

Amelia, L., Hidayanto, A. N., \& Hapsari, I. C. (2011). Analysis of IS/IT service quality in the higher education with SERVQUAL: A case study of STMIK MDP Palembang. The 2 nd International Research Symposium in Service Management, July 26-30, 2011, Yogyakarta, Indonesia.

Coelho, C. D. A. (2004) . Avaliação da qualidade percebida em serviços: aplicação em umcolégio privado de ensino fundamental e médio. Florianópolis, 178 f. issertação (Mestrado em Engenharia de Produção) Programa de Pós-graduação em Engenharia de Produção, Universidade Federal de Santa Catarina.

Davis, B \& West, J. (2002). Re-engineering and Total Quality in schools.London: Pitman.

Douglas J., McClelland, R., \& Davies J. (1993). The development of a conceptual model of student satisfaction with their experience in higher education. Quality Assurance in Education, 16 (1), pp. 1935 .

Gianesi, I.G.N., \& e Correa, H. L. (2004). Administração estratégica em serviços: operações para a satisfação do cliente. São Paulo: Atlas.

Gronroos, C. (1984). A service quality model and its marketing implications. European Journal of Marketing, 18, 36-44. 


\section{The gap between perceptions and expectations Dr. / Abd Al Rahman Osman}

Harris, A \& Preedy, M. (1997). Organizational effectiveness and improvement in education. New York: A wiley Interscience Publication

Harvey, I., \& Knight, P. (1996). Transforming higher education. Society for Research into Higher Education \& Open University Press, Buckingham and London.

Jongbloed, B., Enders, J., \& Salermo, C. (2008). Higher Education and its communities: Interconnections, interdependencies and a research agenda. Higher Education, 56, pp. 303-324.

Khodayari, F., \& Khodayari, B. (2011). Service quality in higher education. Interdisciplinary Journal of Research in Business, 1(9), $38-46$.

Marić, I. (2013). Stakeholder analysis of higher education institutions. Interdisciplinary Description of Complex Systems, 11 (2), pp. 217226

Meirelles, D. S. (2006). O conceito de serviço. Revista Economia Política, vol. 26, n. 1,janeiro/Março, p. 119-136.

Oakland, F. (1995). "A conceptual model of service quality and its implications for future research". Journal of marketing, 61. 41-51.

Parasuraman, A., Berry, L. L., \& Zeithaml, V. A. (1991). Refinement and reassessment of the SERVQUAL scale Journal of Retailing, 67(4), 420-450.

Parasuraman, A., Zeithaml, V. A. \& Berry, L. L. (1985). A conceptual model of service quality and its implications for future research. Journal of Marketing, 49(4), 41-50.

Parasuraman, A., Zeithaml, V. A. \& Berry, L. L. (1988). SERVQUAL: A multiple-item scale for measuring customer perceptions of service quality. Journal of Retailing, 6(41), 12-40.

Pereira, C. (2004). Evolução qualitativa na educação superior. In: OLIVEIRA, O. J. (org.). Gestão da qualidade: tópicos avançados. São Paulo: Thonsom Learning.

Sallis, E. (1993). Total quality management in education. New York:McGraw-Hill.

249

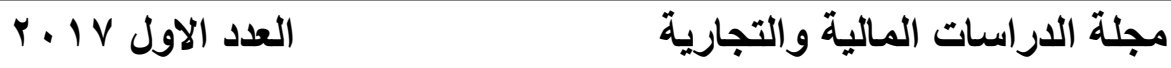

